\title{
Experimental and Research Verification of the Methodology of Forming the High School Students' Artistic Taste for the Vocal Heritage (Late XIX-Early XX Century)
}

\author{
Yuliia V. Merezhko', Dmytro A. Lievit², Oksana P. Petrykova3, \\ Svitlana V. Gmyrina ${ }^{4}$ and Mariia S. Kasianchuk ${ }^{5}$ \\ Department of Academic and Solo Vocal, Institute of Arts, Borys Grinchenko \\ Kyiv University, Kyiv, Ukraine \\ 1https:/ / orcid.org/0000-0001-5918-7496 \\ 2https:/ / orcid.org/0000-0001-6442-3203 \\ 3https:/ / orcid.org/0000-0002-4326-3308 \\ 4https:// orcid.org/0000-0002-3549-2207 \\ ${ }^{5}$ https://orcid.org/0000-0002-6482-9497
}

\begin{abstract}
The article highlights the results of research and experimental work on verifying the methodology of forming the artistic taste of high school students in the vocal heritage of Ukrainian composers of the late XIX - early XX centuries. The study purpose was to evaluate the elaborated methodology for the formation of the artistic taste of high school students in the process of studying the vocal heritage of Ukrainian composers. The study was accomplished using the method of paired comparisons that resulted in the scale of the comparative assessments in the control and the experimental group of high school students during the extracurricular activities in Kyiv, Zaporizhia and Dnipropetrovsk regions. The effectiveness of the proposed method was supported by the results of the statistical purposes of processing the experimental data using the $\chi^{2}$-criterion formula. The criteria for monitoring the formation of the high school students' artistic taste regarding the national heritage of the late XIX-early XX centuries were outlined; the three levels (high, medium, low) of high school students' artistic taste formation were identified. The effectiveness of the applied methodology was evaluated by the series of tests comparing the results at the ascertaining and forming stages of the study. The authors argue that the data of the forming experiment showed significant positive changes in the levels of formation of high school students' artistic taste according to all the determined criteria, which testifies to the effectiveness of the developed facilitation methodology.
\end{abstract}

Keywords: artistic taste; high school students; vocal music teaching; Ukrainian composers; aesthetic education 


\section{Introduction}

At the present stage of societal development, education lies at the basis of intellectual, cultural, spiritual, social, and economic growth of society and the country as a whole (Batalina, 2005; Rostovsky, 2001; Zyazyun 1976). To benefit the educators, practical teaching strategies need to be elaborated to actively advance music education as an essential structure, "a pillar of achieving the comprehensive development of society and a measure of its social and technological progress" (Mahidi, 2019). In accordance with the current approaches, in Ukraine the education system should ensure the formation of a person who is aware of belonging to European civilization and values, clearly oriented inand familiar with modern realities and perspectives of socio-cultural progress. Currently higher education focuses on the successful solution of sociocultural and pedagogical issues related to the guiding the future teachers in the advances of musical and aesthetic pedagogy.

Modern scientific researches show that music and music pedagogy furnish experiences and values for gaining the expected progressive movement of the learners, consistently playing an integral role in the comprehensive, holistic development of the learner's personality (Allsup, 2003; Babayan, 2006; Lebler, 2008; Padalka, 2010).

However, the overwhelming majority of young people nowadays prefer listening to the "light" genre of music (Hemming \& Westvall, 2010; Lebedeva, 2011; Shakhrai, 2003).

Music education in secondary schools of Ukraine encompasses the students of IVIII grades, in contrast high school students remain unattended with the aesthetic knowledge and need guidance to complete education tasks. Unfortunately, the values of national art often stay outside of their reach. Hence, there is a contradiction between the creative potential of the vocal heritage of Ukrainian composers and the prevailing interest of high school students in contemporary music of low quality.

The problem of developing the personality's artistic taste drew the attention of the researchers from various fields of study - philosophers, psychologists, and educators (Abramova, 1998; Babayan, 2006; Vereshchagina, 2010; Vygotsky, 2008). In Ukraine, the dissertation theses of the recent years (Lebedeva, 2011; Ponomaryova, 2007; Popovych, 2005; Sapozhnik, 2001; Shakhrai, 2003, etc.) address the development of aesthetic taste of high school students. In particular the current research studies pedagogical conditions of shaping the aesthetic attitude to reality in the process of learning to play the musical instrument, the method of using popular and variety music in organizing forms of pedagogical influence, developing the aesthetic sphere of high school students and ensuring the aesthetic orientation of their pastime.

At the same time, the problem of instilling the artistic taste in high school students in the process of studying the vocal legacy of Ukrainian composers is almost not considered, as evidenced by Merezhko $(2012,2018)$. The issues of the music pedagogy, in particular the vocal education of high school students in extracurricular activities of the secondary school, remained virtually unaddressed by the researchers, the ways of shaping aesthetic attitude to 
reality of the youth in the process of vocal activity were not sufficiently explored, the possibilities of realizing the aesthetic and educational potential of Ukrainian vocal music have not been addressed. The novelty of the research lies in an attempt to bridge a research gap between the need to enable the facilitating activity of the teacher as regards motivation and persuasion in high school education design and the current targeted drive for the preservation of the values of the national vocal legacy, in particular as reflected in the works of the renowned Ukrainian composers. The study is expedient as the components, criteria and levels of formation of value attitudes of the high school students are explored. Besides, theoretically substantiated and experimentally tested are the pedagogical conditions that contribute to the effective formation of value attitudes in high school students by studying the vocal legacy of the renowned Ukrainian composers at the turn of the XIX-XX centuries.

Researchers showed that in practice, the vocal compositions with the high school students in extra-curricular time are focused primarily on the use of modern "youth" music, under the influence of which the students' artistic taste is formed (Sapozhnik, 2001).

Thus, the purpose of the article is to highlight the results of the analysis of experimental work on verifying the methodology of forming the high school students' artistic taste in the vocal legacy of Ukrainian composers-contributes to elaboration of the state-of-the-art teaching strategy. Thus, the study contributed to the field of music pedagogy the authors' facilitation methodology of shaping musical and aesthetic attitudes of the future teachers, which can be considered as one of the important manifestations of the cultural creativity associated with the preservation, dissemination, enrichment of the values of the national vocal heritage in the life of the contemporary Ukrainian high school students.

\section{Methods}

The methodology of forming young people's artistic taste is aimed specifically at studying the vocal legacy of the Ukrainian composers at the turn of the XIX-XX centuries, in particular Mykola Lysenko, Semen Hulak-Artemovskyi, Sydir Vorobkevych, Yaroslav Barnych, Petro Senyk and others, in extracurricular vocational classes in comprehensive schools.

The proposed methodology includes a set of methods: first, the methods which involve expanding the high school students' awareness of the vocal music of Ukrainian composers at the turn of the XIX-XX centuries; second, the methods aimed at providing the cultural basis of high school students' perception of Ukrainian vocal creativity; third, the methods aimed at stimulating the emotional and evaluative attitude to music, and fourth, the methods aimed at motivating the high school students to express themselves in the process of performing the works of the renowned Ukrainian composers.

The experimental verification of the proposed methodology was applied for several years at the secondary school No. 5 (Pershotravensk), the secondary school No. 25 (Melitopol), the secondary school No. 292 named after hetman Ivan Mazepa (Kyiv), Goroshkivska school of Tetiivsk district in the process of extracurricular work in the framework of secondary school education. 
On the whole, 220 high school students aged 14-16 participated in the experimental study during all steps (ascertaining, forming, final). The verification of the results of the implementation of the developed methodology for the formation of high school students' artistic taste was carried out by the method of ascertaining tests (Nemov, 2001).

\section{Results}

The results of the ascertaining experiment showed that the general level of the formation of the high school students' artistic taste does not meet the requirements established by the regulatory documents. It is manifested, in particular, in the inability of the majority of surveyed students to distinguish the vocal music of high artistic merit from pseudo-arts, inability to give an argumentative evaluation of musical works and their performance, and the inability of the high school students to adequately reproduce the artistic and artistic charge of the vocal compositions, in particular, Ukrainian songs.

The first test session was carried out in the diagnostic block, at the beginning of the forming experiment, to distribute the students of the senior school age into the control and experimental groups. The students' level of artistic taste formation was the main factor in selecting high school students to the control and experimental groups. The students with a top and average level of aesthetic taste formation were put into the control group. The experimental group included low-level students, eight high school students of the secondary school No. 5 (Pershotravensk), eight high school students of the secondary school No. 25 (Melitopol), nine high school students of school No. 292 named after hetman Ivan Mazepa in Kyiv, and eight high school students of Goroshkivska secondary school. Each group comprised of thirty-three students.

\section{Discussion}

The issues of spiritual development of personality, formation of aesthetic attitudes to music heritage, tracing the reality of advances in music education as well as preparation of future teachers for active use of modern approaches in the educational process nowadays become particularly relevant. Nowadays the socio-cultural space is saturated with information, so an important manifestation of the professional culture of the educators is the ability to navigate in the ambience of creative and aesthetic values, deeply perceive, evaluate and interpret works of art, consistently cultivating the learners' interest.

As Campbell and Wiggins (2012), Rudnitskaya (2002), Padalka (2010) note, currently pedagogical education and art are potent factors of personality development. Lewy (1971) outlines and develops the taxonomy of affective educational outcomes of music pedagogy and explores their applicability for the teaching of music in school. Furthermore, Quesada and Terese (1997), Zhang (2018) point that music education activities are at the crossroads of teaching practices. Rodríguez (2019) examines the targeted practices of music education for social development, whereas Mahidi (2019) dwells on practical teaching strategies of musical education in the context of instructional design, in particular, social variables and psychological variables. On the other hand, 
Bradley (2015) focuses on the interculturalist stance of music education as preferred to the multicultural perspective and examines its unintended consequences. As for the national context, art is the process of forming and improving aesthetic education of the younger generation based on the intercultural relations of the art, including the vocal one (Anderson \& Campbell, 1996; Chaciński, 2012). An essential component of this process is the cultivation of personality culture in the aspect of the national ideal of Ukrainian traditions (Fright, 1998; Protsyk, 1982; Shulgina, 2005). Of particular interest are theoretical studies in the field of art and aesthetic education and upbringing of pupils and students, the determination of the list of criteria for aesthetic evaluation, the research addressing the formation of an aesthetic attitude to reality and art.

The relevance of the value approach is also due to the "turning point" of the XX early XXI centuries, which created new ideas about space, time and movement and is determined by the transition to value consciousness. As the teaching practice shows, pupils at secondary educational institutions have little experience in musical works of the renowned Ukrainian composers. The sheer complexity of finding ways of holistic perception of the multidimensional musical world, present-day musical life raises the problem of the formation of value orientations in the musical-pedagogical process is particularly acute.

During the experiment in the control group, the formation of artistic taste was held under the usual conditions of the educational process according to the traditional method and conducted under the direction of music teachers. In the pilot group the high school students studied according to the method developed by the authors. The empirical study involved twelve music teachers and two lecturers from the pedagogical universities in working in an expert commission on summarizing the experiment.

The second test session was conducted at the forming stage of the study to control the experimental process and the third test session was held in the final stage.

At the final stage of the experiment with the view of determining the levels of formation of artistic taste of high school students, the method of content analysis was used. It included the evaluation of the determined indicators by competent referees, such as the teachers of vocal pedagogical universities (National Pedagogical Drahomanov University and Bohdan Khmelnitskyi Melitopol State Pedagogical University).

During the study, a general method was used for all the applied methodologies - the method of pair comparisons since authors worked with two groups of recipients - the control group and the experimental one. This method resulted in the scale of the comparative assessments, expressed in percentage terms.

In the comparative analysis of experimental data of the ascertaining and forming stages of the study, we drew attention to the dynamics of the disclosure of indicators of the creation of the artistic taste levels in the process of studying the Ukrainian heritage of the past according to the criterion "The degree of interest of high school students in art, in particular, the vocal heritage of Ukrainian composers" of the high school students of the experimental and control groups. The questionnaires and the method of "musical and imaginative graphics" were 
used to determine the levels of formation of students' artistic taste. The comparative indicators of the formation of high school students' artistic taste during the study of Ukrainian classical music are presented in Table 1.

Table 1: Dynamics of indicators of forming the artistic taste of the high school students of CG and EG on the criterion "The degree of interest of high school students in art, in particular the vocal heritage of Ukrainian composers"

\begin{tabular}{|c|c|c|c|c|c|c|c|c|c|c|c|c|}
\hline Criteria & \multicolumn{6}{|c|}{$\begin{array}{l}\text { High school students of the CG } \\
\qquad \text { (33 students) }\end{array}$} & \multicolumn{6}{|c|}{$\begin{array}{l}\text { High school students of the } \\
\text { EG (33 students) }\end{array}$} \\
\hline \multirow{3}{*}{$\begin{array}{l}\text { The level of } \\
\text { interest in the } \\
\text { arts, in particular } \\
\text { vocal heritage }\end{array}$} & \multicolumn{12}{|c|}{$\begin{array}{l}\text { Levels of the high school students' artistic taste formation in the } \\
\text { vocal heritage of the renowned Ukrainian composers }\end{array}$} \\
\hline & \multicolumn{2}{|c|}{ low } & \multicolumn{2}{|c|}{ medium } & \multicolumn{2}{|c|}{ high } & \multicolumn{2}{|c|}{ low } & \multicolumn{2}{|c|}{ medium } & \multicolumn{2}{|c|}{ high } \\
\hline & $\begin{array}{l}\stackrel{\infty}{\mathscr{D}} \\
\stackrel{0}{0} \\
\stackrel{D}{0} \\
\infty\end{array}$ & $a^{0}$ & $\frac{\infty}{\stackrel{n}{0}} \frac{0}{0}$ & de & 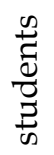 & do &  & do & 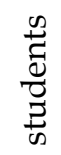 & de & 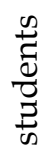 & $\partial^{0}$ \\
\hline $\begin{array}{l}\text { at the beginning } \\
\text { of the experiment }\end{array}$ & $\curvearrowright$ & 每 & 그 & $m^{m}$ & 10 & $\stackrel{\sim}{\sim}$ & $\vec{\lambda}$ & कृ & $a$ & ヘิ & $n$ & a \\
\hline $\begin{array}{l}\text { at the end of the } \\
\text { experiment }\end{array}$ & $\underset{\sqsupset}{\rightleftarrows}$ & 年 & $F$ & $m^{m}$ & $\infty$ & $\stackrel{n}{N}$ & $\Lambda$ & $\widetilde{\text { กे }}$ & $\underset{ت}{\sharp}$ & $\stackrel{4}{\mathfrak{4}}$ & $\stackrel{\sim}{\sim}$ & "ే \\
\hline
\end{tabular}

As illustrated in Table 1, the low level of the artistic taste development of the students of the CG, according to the criterion "The degree of interest of high school students in the vocal heritage" at the end of the experiment declined by $9.1 \%$. However, for the pupils of the EG it fell even more - by $42.4 \%$. The average level in the CG remained the same as it was at the beginning of the study - 33.3\%, the medium level of students of the EG increased by $15.1 \%$; a high level of indicators of the formation of the artistic taste of the CG grew at the end of the experiment by $9.1 \%$, whereas for the high school students of the EG it increased by $27.3 \%$

Consequently, having analyzed the results of this table, we conclude that the level of the formation of the artistic taste according to the criterion "The degree of interest of high school students in the artistic, in particular, the vocal heritage of Ukrainian composers" among the students of the experimental group has enhanced more considerably than that of the CG students. It is due to the use of such methods by the students of the EG, how to make the most of songs of their age, familiarity with the artistic and stylistic features of the vocal heritage of Ukrainian composers, commencing a conversation about the artistic value of music, etc.

At the initial and at the final stage of the experiment, it is expedient to consider the comparative table of the obtained data (see Table 2) by paying attention to the formation of the artistic taste in the students of the senior school age of the control and experimental groups according to the criterion "Measuring the ability to perceive and evaluate the contents of the vocal composition". 
Table 2: Dynamics of indicators of forming the artistic taste of the high school students of CG and EG on the criterion "Ability to perceive and evaluate the contents of vocal composition"

\begin{tabular}{|c|c|c|c|c|c|c|c|c|c|c|c|c|}
\hline Criteria & \multicolumn{6}{|c|}{$\begin{array}{l}\text { High school students of the CG } \\
\text { (33 students) }\end{array}$} & \multicolumn{6}{|c|}{$\begin{array}{l}\text { High school students of the EG } \\
\text { (33 students) }\end{array}$} \\
\hline \multirow{3}{*}{$\begin{array}{l}\text { Ability to } \\
\text { perceive and } \\
\text { evaluate the } \\
\text { content of } \\
\text { vocal } \\
\text { composition }\end{array}$} & \multicolumn{12}{|c|}{$\begin{array}{l}\text { Levels of the high school students' artistic taste formation in the vocal } \\
\text { heritage of the renowned Ukrainian composers }\end{array}$} \\
\hline & \multicolumn{2}{|c|}{ low } & \multicolumn{2}{|c|}{ medium } & \multicolumn{2}{|c|}{ high } & \multicolumn{2}{|c|}{ low } & \multicolumn{2}{|c|}{ medium } & \multicolumn{2}{|c|}{ high } \\
\hline & $\begin{array}{l}\frac{0}{0} \\
\stackrel{0}{0} \\
\frac{0}{0} \\
\frac{D}{\omega}\end{array}$ & $\alpha^{0}$ & $\begin{array}{l}0 \\
\stackrel{D}{ \pm} \\
D_{0}^{0} \\
\frac{D}{\infty}\end{array}$ & $\alpha^{\circ}$ & $\begin{array}{l}\frac{0}{0} \\
\frac{0}{0} \\
\frac{0}{2} \\
\frac{1}{\infty}\end{array}$ & $\alpha^{\circ}$ & 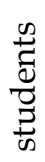 & $\partial^{\circ}$ & $\begin{array}{l}\frac{0}{1} \\
\stackrel{0}{0} \\
\frac{D}{2} \\
\frac{2}{\infty}\end{array}$ & $\partial^{\circ}$ & 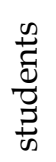 & $\partial^{\circ}$ \\
\hline $\begin{array}{l}\text { at the } \\
\text { beginning of } \\
\text { the } \\
\text { experiment }\end{array}$ & $\stackrel{L}{\sim}$ & 驾 & $\stackrel{ }{7}$ & $\begin{array}{l}\text { H' } \\
\text { లn }\end{array}$ & 0 & $\underset{\sim}{N}$ & $\stackrel{2}{-1}$ & 望 & 욱 & $\begin{array}{l}\text { ? } \\
\text { ô }\end{array}$ & + & $\vec{\sim}$ \\
\hline $\begin{array}{l}\text { at the end of } \\
\text { the } \\
\text { experiment }\end{array}$ & $\stackrel{M}{\sim}$ & ले & $\stackrel{ }{\sim}$ & 品 & $\stackrel{ }{\because}$ & हे & $\infty$ & $\underset{d}{N}$ & $\stackrel{\sim}{\sim}$ & ঠি & $\stackrel{20}{\sim}$ & $\begin{array}{l}\text { 오 } \\
18\end{array}$ \\
\hline
\end{tabular}

The data of the tables show that the indicators of the formation of the artistic taste according to the criterion "Ability to perceive and evaluate the contents of vocal composition" in the students of the CG did not improve significantly: the low level declined by $6 \%$, while the high level increased by $12.1 \%$; the medium level at the last stage of the study declined by $6.1 \%$. The results of the students of the EG showed significant progress towards the enhancement of the state of artistic taste (the low level declined by $33.4 \%$; the high one increased by $33.4 \%$; the medium remained at the same level). The obtained results make it possible to conclude that the state of formation of the artistic taste according to the criterion "Ability to perceive and evaluate the contents of vocal composition" is better in the experimental group of high school students than that of the students of the control group. Thus, it should be noted that the traditional method, aimed at forming meaningful attitude and adequate evaluation of musical works in students, is not sufficiently developed and requires a more thorough study, and the introduced pedagogical methodology enhances both the artistic taste and the ability to perceive and evaluate the contents of the vocal composition.

Determination of the level of formation of the artistic taste of high school students of the control and experimental group according to the criterion "Measuring the ability to express the performance of a musical composition" was carried out with the help of the developed method of performing interpretation. In the process of diagnosis, the following results were obtained (see Table 3). 
Table 3: Dynamics of indicators of forming the artistic taste of the high school students of CG and EG according to the criterion "Measuring the ability to express the performance of a musical composition"

\begin{tabular}{|c|c|c|c|c|c|c|c|c|c|c|c|c|}
\hline Criteria & \multicolumn{8}{|c|}{$\begin{array}{l}\text { High school students of the CG (33 } \\
\text { students) }\end{array}$} & \multicolumn{4}{|c|}{$\begin{array}{c}\text { High school } \\
\text { students of the EG } \\
\text { (33 students) }\end{array}$} \\
\hline \multirow{3}{*}{$\begin{array}{l}\text { Measuring the } \\
\text { ability to express } \\
\text { the performance } \\
\text { of a musical } \\
\text { composition }\end{array}$} & \multicolumn{12}{|c|}{$\begin{array}{l}\text { Levels of the high school students' artistic taste formation in } \\
\text { the vocal heritage of the renowned Ukrainian composers }\end{array}$} \\
\hline & \multicolumn{2}{|c|}{ low } & \multicolumn{2}{|c|}{ medium } & \multicolumn{2}{|c|}{ high } & \multicolumn{2}{|c|}{ low } & \multicolumn{2}{|c|}{ medium } & \multicolumn{2}{|c|}{ high } \\
\hline & 苦 & a & 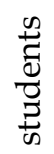 & de & 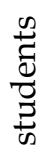 & $\partial^{\circ}$ & 苞 & $\alpha^{\circ}$ & $\frac{\infty}{\stackrel{0}{0}}$ & $\partial^{\circ}$ & 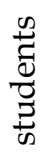 & de \\
\hline $\begin{array}{l}\text { at the beginning } \\
\text { of the experiment }\end{array}$ & $\vec{N}$ & $\begin{array}{l}0 \\
\tilde{\sigma}\end{array}$ & $a$ & $\stackrel{\text { N }}{\text { N }}$ & $n$ & 혀 & ๙ิ & 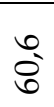 & $\infty$ & $\underset{\mathbb{N}}{\stackrel{N}{N}}$ & 10 & $\underset{\sim}{N}$ \\
\hline $\begin{array}{l}\text { at the end of the } \\
\text { experiment }\end{array}$ & $\stackrel{\sim}{\sim}$ & ボ & 吉 & $\stackrel{+}{+}$ & $\Lambda$ & $\widetilde{N}$ & 6 & $\underset{\infty}{\infty}$ & $\stackrel{0}{\sim}$ & $\begin{array}{l}12 \\
\text { कo }\end{array}$ & $\rightleftharpoons$ & $\tilde{n}^{n}$ \\
\hline
\end{tabular}

The results of the abovementioned table testify to the formation of the artistic taste of the CG high school students in the process of studying the vocal heritage of Ukrainian composers according to the criterion "Measuring the ability to express the performance of a musical composition" at the end of the experiment enhanced in comparison with the results of the initial stage of the experiment, namely: the low level declined by $27.2 \%$; the medium level increased by $15.1 \%$; the high level also increased by $12.1 \%$. Indicators of the formation of the artistic taste of high school students also increased: the low level declined by $42.4 \%$; the medium level increased by $24.3 \%$; the high level also increased by $18.1 \%$. According to the general results of this table, high school students of the EG are overtaking the students of the CG by $12.1 \%$. Remarkable results of the development of the ability to expressly reproduce an artistic composition among students of the experimental group have their own ground.

The process of training high school students of the experimental group to expressly convey the artistic impact of the composition was systematic throughout the experiment with the elaborated methodology. We developed the methodology of public demonstration of vocal achievements, which includes the following techniques: the method of involving students in independent artistic and creative interpretation ("Performance interpretation", "Independent performing analysis of the composition", "Theatrical interpretation", singing of the Ukrainian song with staging performance, etc.); work on vocal and performing techniques in the embodiment of the artistic and creative impact ("Imitation of the reference sample", etc.); doing tasks of performing and creative nature (on the development of artistic, combined imagination); the application of psychological training (to identify oneself as a unique creative personality, to remove physical and emotional stress); compliance phasing in high school students' preparing for the public performance ("Distinguishing of 
individual psychological peculiarities of each singer", "Encouragement to selfcontrol", etc.). Due to the implementation of these methods and techniques the high school students were able to "put themselves in place of the author" of the musical piece, to perceive all the intonation subtleties and to perform the vocal composition deep emotionally and highly artistically, in contrast to the students of the control group.

By determining the levels of the formation of the artistic taste according to the criterion of "Measuring the ability to express the performance of a musical composition" of the high school students of the CG and EG, it is relevant to say that the developed methods, techniques, creative tasks aimed at improving the ability to reproduce the work of art. The results of the table indicate that the ascertaining experiment has enhanced the artistic taste of both high school students of the control group and in the experimental group, but the levels of development of the ability to express the reproduction of the artistic impact of the work is better in the EG than in the CG.

The comparison of the results obtained with the students of the experimental and control groups during the ascertaining experiment made it possible to identify the basic level of formation of their artistic taste according to all the determined criteria (see Table 4).

Table 4: Levels of the artistic taste formation of the high school students of the control and experimental groups at the end of the experiment

\begin{tabular}{|c|c|c|c|c|c|c|c|c|c|c|c|c|}
\hline Criteria & & h s & & ude & $\begin{array}{l}\text { ts of } \\
\text { its) }\end{array}$ & & & $\mathrm{h} \mathrm{scl}$ & & dent & ff th & EG \\
\hline \multirow{4}{*}{$\begin{array}{l}\text { The level of } \\
\text { interest in vocal } \\
\text { heritage }\end{array}$} & \multicolumn{12}{|c|}{$\begin{array}{l}\text { Levels of the high school students' artistic taste formation to the } \\
\text { vocal heritage of the renowned Ukrainian composers }\end{array}$} \\
\hline & \multicolumn{2}{|c|}{ low } & \multicolumn{2}{|c|}{ medium } & \multicolumn{2}{|c|}{ high } & \multicolumn{2}{|c|}{ low } & \multicolumn{2}{|c|}{ medium } & \multicolumn{2}{|c|}{ high } \\
\hline & 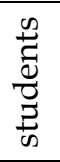 & do & 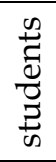 & do & 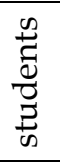 & $\alpha^{0}$ & 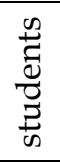 & d゚ & $\begin{array}{l}\frac{}{c} \\
\frac{0}{0} \\
\frac{\vec{D}}{\omega}\end{array}$ & do & 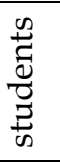 & $\therefore$ \\
\hline & 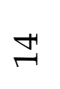 & 辛 & $F$ & $\tilde{m}^{2}$ & $\infty$ & $\stackrel{n}{\stackrel{N}{N}}$ & $\wedge$ & $\stackrel{\text { ก }}{n}$ & $\rightleftarrows$ & भi & I & 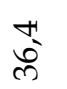 \\
\hline $\begin{array}{l}\text { Ability to perceive } \\
\text { and evaluate the } \\
\text { content of vocal } \\
\text { composition }\end{array}$ & $\stackrel{\infty}{\sim}$ & ले & $\stackrel{ }{\circ}$ & $\begin{array}{c}\text { on } \\
\text { ô }\end{array}$ & $\stackrel{ }{\hookrightarrow}$ & $\begin{array}{l}n \\
\text { ô }\end{array}$ & $\infty$ & $\stackrel{\text { N }}{\underset{N}{N}}$ & 윽 & 品 & $\stackrel{10}{\sim}$ & $\begin{array}{l}\text { 12 } \\
\text { 10 }\end{array}$ \\
\hline $\begin{array}{l}\text { Measuring the } \\
\text { ability to express } \\
\text { the performance } \\
\text { of a musical } \\
\text { composition }\end{array}$ & $\stackrel{\sim}{\sim}$ & $\begin{array}{l}\text { H' } \\
\text { ले }\end{array}$ & 㟔 & $\stackrel{+}{\sim}$ & $\Lambda$ & $\stackrel{N}{\vec{N}}$ & 6 & $\underset{\infty}{\infty}$ & $\stackrel{0}{\sim}$ & $\begin{array}{l}\text { Ln } \\
\stackrel{\infty}{+}\end{array}$ & $\exists$ & $\stackrel{m}{m}^{2}$ \\
\hline General indicators & $\stackrel{M}{\rightarrow}$ & $\begin{array}{l}\text { Hू } \\
\text { ले }\end{array}$ & $\underset{\sim}{ }$ & $\begin{array}{l}m^{2} \\
\dddot{m}^{2}\end{array}$ & $\infty$ & 27 & $\wedge$ & $\frac{N}{\tilde{N}}$ & $\stackrel{m}{\longrightarrow}$ & 苑 & $\stackrel{m}{\rightarrow}$ & 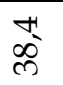 \\
\hline
\end{tabular}


From this table one can see that as a result of the new pedagogical methodology introduced in the educational process, the level of the formation of the artistic taste in the process of studying Ukrainian classical music of high school students of the experimental group exceeds the level of the artistic taste formation by means of Ukrainian classical music of the students of the control group according to all indicators and criteria by $13.1 \%$. The given result testifies to the efficiency of the methodology of forming artistic taste developed by our high school students. Due to the introduction of this method, the results of the students in the senior school age group of the experimental group were as follows: high level - thirteen students, medium - thirteen, low - seven. The distribution of the results in the control group was as follows: 8 students had a high level, twelve students had a medium level, and thirteen students had a low level.

The effectiveness of the suggested methodology is confirmed by the statistical processing the experimental data using the formula $\chi^{2}$-criterion ("chi-squared criterion"):

$$
\mathrm{X}^{2}=\sum_{\mathrm{k}=1}^{\mathrm{m}} \frac{\left(\mathrm{V}_{\mathrm{k}}-\mathrm{P}_{\mathrm{k}}\right)^{2}}{\mathrm{P}_{\mathrm{k}}}
$$

where $P_{k}$ - the results of comments before the experiment; $V_{k}$ - the results of comments after the experiment; $m$ - the total number of the groups to which the results of comments were shared.

a) By substituting the experimental data of the students of the control group in the given formula, we obtained the following results:

$$
X^{2}=\sum_{k=1} \frac{(39.4-53.5)^{2}}{53.5}+\frac{(35.3-32.3)^{2}}{32.3}+\frac{(25.3-14.2)^{2}}{14.2}=12.68
$$

According to the indicators of the students of the control group, the $x$ 2-criterion was 12.68. Using the table 4, where we can determine the degree of significance of the differences obtained at the beginning and end of the experimental study for a given number of degrees of freedom, it was recorded that the value $x^{2}=$ 12.68 is less than the value given in the table $m-1=2$ degrees of freedom, that is equal to 13.82 with a possible error of less than $0.001 \%$. This measurement has shown that studying according to the traditional methodology does not provide the formation of the artistic taste of the high school students by means of the vocal heritage of the renowned Ukrainian composers.

b) By substituting the experimental group's data for the given formula, we obtained the following results:

$$
X^{2}=\sum_{k=1} \frac{(21.2-60.6)^{2}}{60.6}+\frac{(40.4-27.3)^{2}}{27.3}+\frac{(38.4-12.1)^{2}}{12.1}=89.07
$$

According to the indicators of the experimental group, the value of the $x^{2}$ criterion is 89.07 , exceeding the value in the table [10,573], which is 13.82 with a probability of an error of less than $0.001 \%$.

The existing studies prove to be in accordance with the foregoing series of experiments and their design. Suffice to say, that the research done by Mahidi 
(2019) relies heavily on the prerequisites such as the teacher's familiarity with the music education design, the goals sequence for learner's perception, their success motivation and appropriateness of the chosen goals and activities against the national context and the existing culturally-specific attitudes towards the effects of music as directly addressed to the deeply rooted determinants of the national spirit and national identity. The measurements obtained in the experiment expressly showed the appropriateness of measuring the learner's success, studying according to the suggested authors' methodology, that ensures the deeper awareness and desired acquisition of the artistic taste of the high school students and their perceptions of the vocal heritage of the renowned Ukrainian composers since cultural education of a person should possess a pronounced national character (Kablova \& Pavlova, 2017).

\section{Conclusions}

Music education is shown to enhance the spiritual culture of the high school students who were embraced by the experimental study, to guide them in the historical experience and heritage of the nation. The verification of the research findings on the example of the high school students of the experimental group convincingly illustrates the high efficiency of the methodology introduced in the educational process. The method was aimed at forming the artistic taste of the high school students in the process of studying the vocal heritage of the renowned Ukrainian composers. The dynamics of achievements of the high school students of the experimental group testifies to the effectiveness of the proposed methodology of forming artistic taste in the process of studying the vocal heritage of Ukrainian composers.

Thus, the authors' method of shaping aesthetic attitude to reality in extracurricular music-creative activity was substantiated and experimentally tested. The criteria and levels of formation of this phenomenon in students were given detailed study. The results of the forming experiment are analysed and their reliability is proved. According to the foregoing, the essence of music as a form of the artistic creativity is taken as a ground for its understanding in music pedagogy, reflecting the inherent infinity and immense power to affect the spiritual culture of the high school students.

\section{References}

Abramova, G. (1998). Age psychology: coursebook for graduate students. Moscow, Russia: Academy Publishing Center.

Allsup, R. E. (2003). Transformational education and critical music pedagogy: Examining the link between culture and learning. Music Education Research, 5(1), 5-12.

Anderson, W. M., \& Campbell, P. S. (Eds.), (1996). Multicultural Perspectives in Music Education ( $2^{\text {nd }}$ ed). Reston, VA: Music Educators National Conference.

Babayan, A. G. (2006). Formation of aesthetic value orientations of high school students in the educational process ( $\mathrm{PhD}$ abstract). Moscow State Linguistic University, Moscow.

Batalina, G. (2005). The system of aesthetic education of high school students in a secondary school (PhD abstract). Volodymyr Dahl East Ukrainian National University, Luhansk. 
Bradley, D. (2015). The dynamics of multiculturalism in music matters: a philosophy of music education. Action, Criticism, and Theory for Music Education, 14, 10-26.

Campbell, P. S., \& Wiggins, T. (Eds.) (2012). The Oxford handbook of children's musical cultures. Oxford, UK: Oxford University Press.

Chaciński, J. (2012). Intercultural Teaching of Music at School as a Form of Dialogue and Meeting of Youth from Neighbouring Countries: Poland, Germany and Ukraine. Gdańsk, Poland: Akademia Muzyczna im. St. Moniuszki w Gdańsku.

Fright, I. V. (1998). Problems of musical education of schoolchildren in the activity of Western Ukrainian composers (second half of XIX - beginning of XX century) (PhD abstract thesis). Vasyl Stefanyk Precarpathian National University, Ivano-Frankivsk.

Hemming, G. E., \& Westvall, M. (2010). Music education - a personal matter? Examining the current discourses of music education in Sweden. British Journal of Music Education, 27(1), 21-33. https://doi.org/10.1017/S0265051709990179

Kablova, T., \& Pavlova, S. (2017). Ukrainian folk songs in music education of pupils. Musical Art in the Educological Discourse, 2, 128-132. https://doi.org/10.28925/2518-766X.20172.12832

Lebedeva, A. V. (2011). The formation of pupils' aesthetic attitude to reality in the extracurricular music and creative activities (PhD thesis). Mykhailo Kotsyubinsky Vinnitsa State Pedagogical University, Vinnytsia.

Lebler, D. (2008). Popular music pedagogy: Peer learning in practice. Music Education Research, 10(2), 193-213. https:/ / doi.org/10.1080/14613800802079056

Lewy, A. (1971). Affective Outcomes of Musical Education. Journal of Research in Music Education, 19(3), 361-365. https://doi.org/10.2307/3343773

Mahidi, S. (2019). The foundations of teaching music education (Unpublished thesis). University of Baghdad, Baghdad. https://doi.org/10.13140/RG.2.2.27406.10565

Merezhko, Y. (2012). Formation of the artistic preferences of high school students in the process of learning the vocal heritage of the Ukrainian composers (Doctoral thesis). National Pedagogical Dragomanov University, Kyiv.

Merezhko, Y. (2018). Experimental technique of formation of the artistic tastes of pupils in the process of Ukrainian vocal heritage studying (the end of XIX - the beginning of XX century). Fundamental and applied researches in practice of leading scientific schools, 26(2), 103-112.

Nemov, R. (2001). Psychodiagnostics. Introduction to scientific and psychological research with the elements of mathematical statistics. Moscow, Russia: VLADOS.

Padalka, G. (2010). Pedagogy of art: theory and methodology of teaching artistic disciplines. Kyiv, Ukraine: Ukraine education.

Ponomaryova, O. M. (2007). Formation of musical and aesthetic orientations of future teachers in extracurricular activities (PhD abstract thesis). Luhansk T. Shevchenko National Pedagogical University, Luhansk.

Popovych, N. M. (2005). Pedagogical conditions of development of the artistic taste in accordion students using a variety arts (PhD abstract thesis). Kyiv National University of Culture and Arts, Kyiv.

Protsyk, S. (1982). The contribution of Ukrainian composers to the theory and practice of musically aesthetic education of students. Music at School, 8, 52-57.

Quesada, M. A., \& Terese, M. V. (1997). World musics and music education: a review of research, 1973-1993. Bulletin of the Council for Research in Music Education, 131, 4466.

Rodríguez, O. (2019). Music education and social development. Innovare: Revista de ciencia y tecnología, 8, 124-127. https://doi.org/10.5377/innovare.v8i2.8953 
Rostovsky, O. (2001). Musical pedagogy: educational programs, methodical recommendations and materials. Nizhyn, Ukraine: NDPU.

Rudnitskaya, O. (2002). Pedagogics: general and artistic. Kyiv, Ukraine: IPPE.

Sapozhnik, O. V. (2001). Musical and aesthetic education of high school students (based on contemporary popular pop music) (PhD abstract thesis). Kyiv National University of Culture and Arts, Kyiv.

Shakhrai, V. M. (2003). Formation of adolescents' value orientations in children's theatre activity (PhD abstract thesis). Institute of Educational Problems of APS of Ukraine, Kyiv.

Shulgina, V. (2005). Ukrainian musical pedagogy. Kyiv, Ukraine: DACKIM.

Vereshchagina, O. (2010). History of Ukrainian music of the XX century: a tutorial. Kyiv, Ukraine: Education of Ukraine.

Vygotsky, L. (2008). Pedagogical psychology. Moscow, Russia: AST, Astrel.

Zhang, H. (2018). The aesthetic education of vocal music teaching in music education. In Z. Wang (Ed.), Proceedings of the 8th International Conference on Social Science and Education Research (SSER 2018) (pp. 16-19). Beijing, China: Atlantis Press. https:// doi.org/10.2991/sser-18.2018.4

Zyazyun, I. (1976). Aesthetic experience of the personality. Formation and spheres of influence. Kyiv, Ukraine: Higher school. 